\title{
Effect of nanosecond electropulse effects on the properties of the alloy $\mathrm{Cu}-1.75 \% \mathrm{Cr}$
}

\author{
Igor E. Ignatiev, ${ }^{1}$ * Pavel V. Kotenkov, ${ }^{1}$ Valery V. Krymsky, ${ }^{2}$ \\ Elena V. Ignatieva, ${ }^{1+}$ and Eduard Yu. Goyda ${ }^{1}$ \\ ${ }^{1}$ Institute of Metallurgy, Ural Branch of the Russian Academy of Sciences. Amundsen St., 101. \\ Ekaterinburg, 620016. Russia.Phone:+7 (343)232-90-14.E-mail: igx2@mail.ru \\ ${ }^{2}$ South Ural State University. Etc. Lenin, 76. Chelyabinsk, 454080. Russia. \\ Phone: +7 (351) 267-90-14. E-mail:kvv@susu.as.ru
} \begin{abstract}
Keywords: copper-chromium alloy, melt, electropulse effect, electrical resistance, hardness.
\end{abstract}
*Supervising author; ${ }^{+}$Corresponding author

\begin{abstract}
The hardness, electrical resistance, deformation resistance of the $\mathrm{Cu}-1.75 \% \mathrm{Cr}$ alloy obtained by irradiating its melt at a temperature of one thousand three hundred and fifty degrees Celsius by nanosecond unipolar electrical pulses of one thousand Hertz, a single signal duration of one nanosecond and ten kilowatts were experimentally determined. The dependences of the determined properties of the metal on the duration of the electric pulse irradiation are established. A comparison was made between irradiated and unirradiated, but obtained under the same thermal and temporal conditions, alloy samples. An improvement was observed in both mechanical (increase in hardness up to eight percent) and electrical (decrease in electrical resistance to fourteen and a half percent) characteristics due to electric pulse effect on the melt. It was found that the best time for electropulse treatment is from five to ten minutes. It is shown that the effect of irradiation of the $\mathrm{Cu}$ $1.75 \% \mathrm{Cr}$ melt on the electrical resistance of the resulting alloy and its hardness differs from the results of irradiation of the $\mathrm{Cu}-1 \% \mathrm{Cr}$ melt, but retains the same tendencies in changing properties. A significant difference was found in the hardness values of unirradiated samples of $\mathrm{Cu}-1.75 \% \mathrm{Cr}$ and $\mathrm{Cu}-1 \% \mathrm{Cr}$ alloys. A model of the connection of electrical resistance and hardness of $\mathrm{Cu}-\mathrm{Cr}$ alloys with the redistribution of chromium in their volume is proposed. The results of melt processing by nanosecond unipolar electric pulses are presented in the form of microstructure snapshots, tables, and mathematical formulas. On the basis of the obtained results, it was concluded that the proposed model is useful for assessing the quality of $\mathrm{Cu}$-Cr system alloys from the standpoint of increasing their hardness and decreasing electrical resistance, including after electropulse treatment of the corresponding melts.
\end{abstract}

\section{References}

[1] O.E. Osintsev, V.N. Fedorov. Copper and copper alloys. Domestic and foreign brands: a directory. 2nd ed., Pererab. and add. Moscow: Innovative Engineering. 2016. 360p. (russian)

[2] Yuan Yuan, Zhou Li, Zhu Xiao, Ziqian Zhao, Ziqi Yang. Microstructure evolution and properties of Cu$\mathrm{Cr}$ alloy during continuous extrusion process. Journal of Alloys and Compounds. 2017. Vol.703. P.454460.

[3] Lijun Peng, Haofeng Xie, Guojie Huang \& others. The phase transformation and strengthening of a Cu$0.71 \mathrm{wt} \%$ Cr alloy. Journal of Alloys and Compounds 2017. Vol.708. P.1095-1102.

[4] M.A. Eremina, S.F. Lomaeva, E.P. Elsukov, L.E. Bodrova, E.Yu. Goida, E.A. Pastuhov. Copperchromium carbide composites produced by mechanical activation of initial components in the solid and liquid states. Khim. Fiz. Mezosk. 2013. Vol.15. No.2. P.262-269. (russian)

[5] V.P. Korzhov, M.I. Karpov, V.I. Vnukov. Structure and properties of arc-melted $\mathrm{Cu}-2 \% \mathrm{Cr}$ chromium bronze. Metal Science and Heat Treatment. 2009. No.8. P.21-25. (russian)

[6] Jiamin Zhou, Degui Zhu, Liuting Tang, Xiaosong Jiang, Song Chen, Xu Peng, Chunfeng Hu. Microstructure and properties of powder metallurgy $\mathrm{Cu}-1 \% \mathrm{Cr}-0.65 \% \mathrm{Zr}$ alloy prepared by hot pressing. Vacuum. 2016. Vol.131. P.156-163.

[7] N.E. Fomin, V.I. Ivlev, V.A. Yudin. Effect of impurities on the electrical resistivity of copper and aluminum Mordovia University Bulletin. 2014. No.1. P.50-56. (russian)

[8] V.F. Balakirev, V.V. Krymskii, E.H. Ri, Ri Hosen, N.A. Shaburova. Electropulse treatment of metal melts. Ekaterinburg: UB RAN. 2014. 144p. (russian) 
[9] D.V. Shangina, N.R. Bochvar, A.I. Morozova, A.N. Belyakov, R.O. Kaibyshev, S.V. Dobatkin. Effect of chromiumand zirconium content on structure, strength and electrical conductivity of $\mathrm{Cu}-\mathrm{Cr}-\mathrm{Zr}$ alloys after high pressure torsion. Materials Letters. 2017. Vol.199. P.46-49.

[10] E.Y. Goyda, V.V. Krimsky, I.E. Ignatiev, P.V. Kotenkov, A.V. Dolmatov, V.F. Балакирев, and E.V. Ignateva. The influence of unipolar nanosecond electropulse effects on the properties of the alloy $\mathrm{Cu}-$ $1 \% \mathrm{Cr}$. The connection properties of the alloy with the duration of melt processing. Butlerov Communications. 2018. Vol.53. No.2. P.145-152. DOI: 10.37952/ROI-jbc-01/18-53-2-145

[11] I.E. Ignatiev, P.V. Kotenkov, E.Yu. Goyda, E.V. Ignatieva, and V.V. Krymsky. Effect of nanosecond unipolar electropulse effects on the properties of the alloy $\mathrm{Cu}-1 \% \mathrm{Cr}$. Part 2. Relation of alloy properties with $\mathrm{Cr}$ content in Cu lattice. Butlerov Communications. 2019. Vol.57. No.1. P.127-134. DOI: $10.37952 /$ ROI-jbc-01/19-57-1-127

[12] I.E. Ignatev, V.V. Krymskij, P.V. Kotenkov, V.F. Balakirev, E.A. Pastukhov, E.V. Ignateva. Manufacture method of composite alloys and plant for its implementation. Patent RF, no. 2625375 , 13.07.2017 Bull. No.20. (russian)

[13] Z.M. Zhou, Z.P. Xiao, B.W. Wei, Y.Hu, L.W. Tang, C. Liu. The Numerical Simulation of Rapidly Solidified Cu-Cr Alloys. Procedia Engineering. 2012. Vol.29. P.3944-3948.

[14] Kun Xia Wei, Wei Wei, Fei Wang, Qing Bo Du, I.V. Alexandrov, Jing Hu. Microstructure, mechanical properties and electrical conductivity of industrial $\mathrm{Cu}-0.5 \% \mathrm{Cr}$ alloy processed by severe plastic deformation. Materials Science and Engineering: A. 2011. Vol.528. Iss.3. P.1478-1484.

[15] H.E. Wen-xiong, Y.U. Yang, Er-de WANG, Hong-fei SUN, Hui CHEN. Microstructures and properties of cold drawn and annealed submicron crystalline $\mathrm{Cu}-5 \% \mathrm{Cr}$ alloy. Transactions of Nonferrous Metals Society of China. 2009. Vol.19. Iss.1. P.93-98.

[16] Milan Bizjak, Blaž Karpe, Gregor Jakša, Janez Kovač. Surface precipitation of chromium in rapidly solidified $\mathrm{Cu}-\mathrm{Cr}$ alloys. Applied Surface Science. 2013. Vol.277. P.83-87.

[17] E.H. Ri, Ri Hosen, S.V. Dorofeev, V.I. Yakimov. Influence of an irradiation of a liquid phase by nanosecond electromagnetic impulses (NEMI) on its structure, crystallization and structure formation processes and properties of casting alloys. Vladivostok Dal'nauka. 2008. 176p. (russian)

[18] E.Yu. Goyda, I.E. Ignatiev, and A.B. Shubin On the microhardness of the composite Ga-Cu-Sn obtained multivibration the processing idkategori mixture. Butlerov Communications. 2018. Vol.56. No.10. P.112-117. DOI: $10.37952 /$ ROI-jbc-01/18-56-10-112

[19] I.E. Ignatiev, and E.V. Ignatieva. On the question of improving the low-frequency method of processing metal melts. Butlerov Communications. 2018. Vol.54. No.5. P.138-144. DOI: 10.37952/ROI-jbc-01/1854-5-138

[20] W. Wang, C. Li, Y. Wu, P. Zhang. Preparation and properties of $\mathrm{Cu}-\mathrm{Cr}-\mathrm{C}$ self-lubricated composite. Hot working technol. 2010. Vol.22. P.72-74.

[21] S. Zhanbo, W. Youhong, G. Juan, et al. Liquid and solid phase separation during melt spinning and annealing in melt-spun $\mathrm{Cu}-\mathrm{Cr}$ ribbons. Materials Science and Engineering A. 2007. P.452-453. 